\title{
Front Matter: Volume 6673
}

, "Front Matter: Volume 6673," Proc. SPIE 6673, Time and Frequency Metrology, 667301 (17 September 2007); doi: 10.1117/12.773495

SPIE Event: Optical Engineering + Applications, 2007, San Diego, California, United SPIE. States 


\section{PROCEEDINGS OF SPIE}

\section{Time and Frequency Metrology}

R. Jason Jones

Editor

29-30 August 2007

San Diego, California, USA

Sponsored and Published by

SPIE

Volume 6673

Proceedings of SPIE, 0277-786X, v. 6673 
The papers included in this volume were part of the technical conference cited on the cover and title page. Papers were selected and subject to review by the editors and conference program committee. Some conference presentations may not be available for publication. The papers published in these proceedings reflect the work and thoughts of the authors and are published herein as submitted. The publisher is not responsible for the validity of the information or for any outcomes resulting from reliance thereon.

Please use the following format to cite material from this book:

Author(s), "Title of Paper," in Time and Frequency Metrology, edited by R. Jason Jones, Proceedings of SPIE Vol. 6673 (SPIE, Bellingham, WA, 2007) Article CID Number.

ISSN 0277-786X

ISBN 9780819468215

Published by

SPIE

P.O. Box 10, Bellingham, Washington 98227-0010 USA

Telephone +1 3606763290 (Pacific Time) · Fax +1 3606471445

SPIE.org

Copyright (C 2007, Society of Photo-Optical Instrumentation Engineers

Copying of material in this book for internal or personal use, or for the internal or personal use of specific clients, beyond the fair use provisions granted by the U.S. Copyright Law is authorized by SPIE subject to payment of copying fees. The Transactional Reporting Service base fee for this volume is $\$ 18.00$ per article (or portion thereof), which should be paid directly to the Copyright Clearance Center (CCC), 222 Rosewood Drive, Danvers, MA 01923. Payment may also be made electronically through CCC Online at copyright.com. Other copying for republication, resale, advertising or promotion, or any form of systematic or multiple reproduction of any material in this book is prohibited except with permission in writing from the publisher. The CCC fee code is $0277-786 \mathrm{X} / 07 / \$ 18.00$.

Printed in the United States of America.

Publication of record for individual papers is online in the SPIE Digital Library.

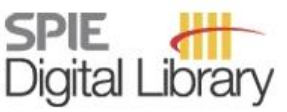

SPIEDigitallibrary.org

Paper Numbering: Proceedings of SPIE follow an e-First publication model, with papers published first online and then in print and on CD-ROM. Papers are published as they are submitted and meet publication criteria. A unique, consistent, permanent citation identifier (CID) number is assigned to each article at the time of the first publication. Utilization of CIDs allows articles to be fully citable as soon they are published online, and connects the same identifier to all online, print, and electronic versions of the publication. SPIE uses a six-digit CID article numbering system in which:

- The first four digits correspond to the SPIE volume number.

- The last two digits indicate publication order within the volume using a Base 36 numbering system employing both numerals and letters. These two-number sets start with 00, 01, 02, 03, 04, 05, $06,07,08,09,0 A, 0 B \ldots 0 Z$, followed by $10-12,20-2 Z$, etc.

The CID number appears on each page of the manuscript. The complete citation is used on the first page, and an abbreviated version on subsequent pages. Numbers in the index correspond to the last two digits of the six-digit CID number. 


\section{Contents}

vii Conference Committee

\section{SESSION 1 OPTICAL CLOCKS I: IONS}

667303 Optical frequency standards based on mercury and aluminum ions (Invited Paper) [6673-02]

W. M. Itano, J. C. Bergquist, A. Brusch, S. A. Diddams, T. M. Fortier, T. P. Heavner, L. Hollberg, D. B. Hume, S. R. Jefferts, L. Lorini, T. E. Parker, T. Rosenband, J. E. Stalnaker, National Institute of Standards and Technology (USA)

667305 High-resolution spectroscopy of the ${ }^{88} \mathrm{Sr}^{+}$single ion optical frequency standard (Invited Paper) [6673-04]

P. Dubé, A. A. Madej, J. E. Bernard, A. D. Shiner, National Research Council of Canada (Canada)

\section{SESSION 2 PORTABLE CLOCKS AND STANDARDS}

$667306 \mathrm{Hg}$ ion atomic clock for deep space navigation and science (Invited Paper) [6673-05] J. D. Prestage, S. K. Chung, L. Lim, T. Le, Jet Propulsion Lab. (USA)

667307 Advances in chip-scale atomic frequency references at NIST (Invited Paper) [6673-06] S. Knappe, National Institute of Standards and Technology (USA); V. Shah, A. Brannon, The Univ. of Colorado, Boulder (USA); V. Gerginov, The Univ. of Notre Dame (USA);

H. G. Robinson, National Institute of Standards and Technology (USA); Z. Popović, The Univ. of Colorado, Boulder (USA); L. Hollberg, J. Kitching, National Institute of Standards and Technology (USA)

667308 The space program PHARAO/ACES (Invited Paper) [6673-07]

Ph. Laurent, LNE-SYRTE (France); M. Abgrall, ALTEN SO (France); A. Clairon, P. Lemonde, G. Santarelli, LNE-SYRTE (France); C. Salomon, ENS-LKB (France); F. Picard, C. Sirmain,

D. Massonnet, CNES (France); L. Cacciapuoti, ESA, ESTEC (Netherlands)

\section{SESSION 3 ATOMIC FOUNTAIN CLOCKS}

667309 NIST cesium fountains: current status and future prospects (Invited Paper) [6673-08] S. R. Jefferts, T. P. Heavner, T. E. Parker, J. H. Shirley, National Institute of Standards and Technology (USA)

6673 OA Manipulation of the collisional frequency shift in caesium fountain clocks (Invited Paper) [6673-09]

K. Szymaniec, W. Chalupczak, National Physical Lab. (United Kingdom); S. Weyers, R. Wynands, Physikalisch-Technische Bundesanstalt (Germany); E. Tiesinga, C. J. Williams, National Institute of Standards and Technology (USA) 
6673 OB Comparisons between 3 fountain clocks at LNE-SYRTE (Invited Paper) [6673-10]

F. Chapelet, J. Guéna, D. Rovera, P. Laurent, P. Rosenbusch, G. Santarelli, S. Bize,

A. Clairon, LNE-SYRTE, Observatoire de Paris (France); M. E. Tobar, Univ. of Western Australia (Australia); M. Abgrall, CNES (France)

\section{SESSION 4 OPTICAL CLOCKS II: NEUTRALS}

6673 OC Ultra-high resolution spectroscopy with a ${ }^{87}$ Sr optical lattice clock (Invited Paper) [6673-11] G. K. Campbell, M. Boyd, A. Ludlow, S. Foreman, T. Zelevinsky, S. Blatt, T. Zanon, M. Miranda, M. Martin, J. Ye, JILA, National Institute of Standards and Technology (USA) and Univ. of Colorado, Boulder (USA)

6673 OD Present status of the development of an Yb optical lattice clock at NMIJ/AIST (National Metrology Institute of Japan/National Institute of Advanced Industrial Science and Technology) [6673-12]

M. Yasuda, F.-L. Hong, National Institute of Advanced Industrial Science and Technology (Japan) and Japan Science and Technology Agency (Japan); T. Kohno, Japan Science and Technology Agency (Japan); H. Inaba, K. Hosaka, National Institute of Advanced Industrial Science and Technology (Japan) and Japan Science and Technology Agency (Japan); C. Willis, T. Kurosu, A. Onae, National Institute of Advanced Industrial Science and Technology (Japan); S. Ohshima, National Institute of Advanced Industrial Science and Technology (Japan) and Japan Science and Technology Agency (Japan)

6673 OE Lattice-based optical clock using an even isotope of Yb (Invited Paper) [6673-13] Z. W. Barber, National Institute of Standards and Technology (USA) and Univ. of Colorado, Boulder (USA); C. W. Hoyt, Bethel Univ. (USA); J. E. Stalnaker, National Institute of Standards and Technology (USA); N. Lemke, National Institute of Standards and Technology (USA) and Univ. of Colorado, Boulder (USA); C. W. Oates, T. M. Fortier, S. Diddams, L. Hollberg, National Institute of Standards and Technology (USA)

6673 OF Prospect for a compact strontium optical lattice clock (Invited Paper) [6673-14] N. Poli, R. E. Drullinger, G. Ferrari, LENS Istituto Nazionale Fisica della Materia, CNR, Istituto Nazionale di Fisica Nucleare, Univ. di Firenze (Italy); M. Prevedelli, Univ. di Bologna (Italy); F. Sorrentino, LENS Istituto Nazionale Fisica della Materia, CNR, Istituto Nazionale di Fisica Nucleare, Univ. di Firenze (Italy); M. G. Tarallo, LENS Istituto Nazionale Fisica della Materia, CNR, Istituto Nazionale di Fisica Nucleare, Univ. di Firenze (Italy) and Istituto Nazionale di Fisica Nucleare (Italy); G. M. Tino, LENS Istituto Nazionale Fisica della Materia, CNR, Istituto Nazionale di Fisica Nucleare, Univ. di Firenze (Italy)

\section{SESSION 5 FS COMBS AND FREQUENCY TRANSFER}

6673 OG Precise time and frequency transfer link used for the uncertainty evaluation of Sr. optical lattice clock (Invited Paper) [6673-15] M. Imae, Y. Fujii, F. Hong, National Metrology Institute of Japan/AIST, CREST, Japan Science and Technology Agency (Japan); M. Takamoto, R. Higashi, H. Katori, The Univ. of Tokyo, CREST (Japan) 
$6673 \mathrm{OH}$ Coherent fiber-based frequency combs and CW lasers at $1550 \mathrm{~nm}$ (Invited Paper) [6673-16]

N. R. Newbury, W. C. Swann, I. Coddington, P. A. Williams, National Institute of Standards and Technology (USA)

\section{SESSION 6 FS COMBS AND PRECISION SPECTROSCOPY}

6673 OK High-precision spectroscopy of antiprotonic helium atoms using femtosecond frequency comb, and related topics in low-energy antiproton physics (Invited Paper) [6673-19]

H. A. Torii, The Univ. of Tokyo (Japan)

\section{POSTER SESSION}

667300 A precise length etalon generator controlled by femtosecond mode-locked laser [6673-23] R. Šmíd, O. Číp, J. Lazar, Institute of Scientific Instruments (Czech Republic)

$6673 \mathrm{OP} \quad$ Absolute frequency shifts of iodine cells for laser stabilization [6673-24] J. Lazar, J. Hrabina, F. Petrů, P. Jedlička, O. Číp, R. Šmíd, Institute of Scientific Instruments (Czech Republic)

$66730 Q \quad$ A compact and efficient hyper coherent light source of visible violet laser diode based on Pound-Drever-Hall technique [6673-25]

W. Sasaki, H. Yashiro, Y. Miura, K. Mizutani, J. Nakajima, Doshisha Univ. (Japan)

6673 OR High-precision thermal expansion measurements using small Fabry-Perot etalons [6673-26] M. J. Davis, J. S. Hayden, SCHOTT North America, Inc. (USA); D. L. Farber, Lawrence Livermore National Lab. (USA)

6673 OT Compact and inexpensive frequency stabilization technique for $850-\mathrm{nm}$ vertical cavity surface emitting lasers based on Fabry-Perot resonator [6673-28]

Y. Miura, J. Nakajima, K. Mizutani, W. Sasaki, Doshisha Univ. (Japan) 
Downloaded From: https://www.spiedigitallibrary.org/conference-proceedings-of-spie on 26 Apr 2023

Terms of Use: https://www.spiedigitallibrary.org/terms-of-use 


\title{
Conference Committee
}

\author{
Conference Chair
}

R. Jason Jones, College of Optical Sciences, The University of Arizona (USA)

Program Committee

James C. Bergquist, National Institute of Standards and Technology (USA)

Andre Clairon, Observatoire de Paris (France)

Peter J. Delfyett, Jr., College of Optics \& Photonics, University of Central Florida (USA)

Patrick Gill, National Physical Laboratory (United Kingdom)

Feng-Lei Hong, National Institute of Advanced Industrial Science and Technology (Japan) and CREST, Japan Science and Technology Agency (Japan)

Tetsuya Ido, National Institute of Information and Communications Technology (Japan)

David J. Jones, The University of British Columbia (Canada)

Ekkehard Peik, Physikalisch-Technische Bundesanstalt (Germany)

John D. Prestage, Jet Propulsion Laboratory (USA)

Thomas Udem, Max-Planck-Institut für Quantenoptik (Germany)

Jun Ye, JILA, National Institute of Standards and Technology (USA) and University of Colorado, Boulder (USA)

Session Chairs

$1 \quad$ Optical Clocks I: lons

John D. Prestage, Jet Propulsion Laboratory (USA)

2 Portable Clocks and Standards

Patrick Gill, National Physical Laboratory (United Kingdom)

3 Atomic Fountain Clocks

Nathan R. Newbury, National Institute of Standards and Technology (USA)

4 Optical Clocks II: Neutrals

Chad W. Hoyt, Bethel University (USA) 
$5 \quad$ FS Combs and Frequency Transfer

R. Jason Jones, College of Optical Sciences, The University of Arizona (USA)

$6 \quad$ FS Combs and Precision Spectroscopy

Feng-Lei Hong, National Institute of Advanced Industrial Science and Technology (Japan) and CREST, Japan Science and Technology Agency (Japan) 